\title{
Extraction of Kaempferitrin and Astragalin from Justicia Spicigera by Supercritical Fluid Extraction and Its Comparison with Conventional Extraction
}

\author{
Sandro Cid-Ortega ${ }^{1,2^{*}}$, José Alberto Monroy-Rivera ${ }^{1}$, Óscar González-Ríos ${ }^{1}$ \\ 1. Technological National of Mexico/Technological Institute of Veracruz, Research and Development Unit in \\ Foods (UNIDA), Calzada Miguel Ángel de Quevedo No. 2779, Formando Hogar 91897, Veracruz, Veracruz, \\ Mexico \\ 2. Technological University of Izúcar de Matamoros (UTIM), Department of Food Process Engineering, \\ Prolongación Reforma No. 168, Barrio de Santiago Mihuacán 74420, Izúcar de Matamoros, Puebla, Mexico \\ E-mail: oscargr@itver.edu.mx; scidortega@hotmail.com(Corresponding author)
}

Received: 12 June 2021; Accepted: 6 August 2021; Available online: 10 October 2021

\begin{abstract}
A study of supercritical fluid $\mathrm{CO}_{2}$ extraction of kaempferitrin (KM) and astragalin (KG) from Justicia spicigera (muicle) was conducted. A $3^{3}$ Box-Behnken design was used to analyze the effects of pressure (200-300 bar), temperature $\left(40-60^{\circ} \mathrm{C}\right)$, and co-solvent flow rate $(0.5-1.0 \mathrm{~mL} / \mathrm{min})$. The highest $\mathrm{KM}$ and $\mathrm{KG}$ concentration were achieved at a pressure of $300 \mathrm{bar}$, a temperature of $60^{\circ} \mathrm{C}$, and co-solvent flow rate of $1.0 \mathrm{~mL} / \mathrm{min}$ (ethanol $99.5 \%$ ), with a constant $\mathrm{CO}_{2}$ flow rate of $5 \mathrm{~mL} / \mathrm{min}$ and extraction time of $180 \mathrm{~min}$. Under these conditions, the experimental values for KM and KG (115.08 \pm 2.81 and 56.63 $\pm 9.02 \mathrm{mg} / 100 \mathrm{~g}$ of dry powder, respectively) were similar to those calculated by the models ( 109.0 and $44.07 \mathrm{mg} / 100 \mathrm{~g}$ of dry powder, respectively). The use of 70 $\%$ ethanol as co-solvent in the supercritical extraction process considerably improved the yields of KM and KG (562.71 \pm 156.85 and $79.90 \pm 18.03 \mathrm{mg} / 100 \mathrm{~g}$ of dry powder, respectively) compared to the $99.5 \%$ ethanol extractions. The conventional extraction showed the highest yields of KM and KG (574.20 \pm 65.10 and $113.10 \pm 15.06 \mathrm{mg} / 100 \mathrm{~g}$ of dry powder, respectively) at $70^{\circ} \mathrm{C}$ and extraction time of $120 \mathrm{~min}$. Adequate yields were achieved of KM and KG by supercritical fluid extraction compared with conventional extraction (98 and 70 $\%$, respectively); therefore supercritical fluid extract of $J$. spicigera could be used in the development of functional foods, as well as its possible use in traditional medicine by the health professionals.
\end{abstract}

Keywords: Astragalin; Justicia spicigera; Kaempferitrin; Supercritical fluid extraction.

\section{Introduction}

The use of medicinal plants in alternative medicine to treat various ailments or diseases (respiratory, circulatory, digestive, genitourinary, musculoskeletal and nervous systems; endocrine, nutritional and metabolic diseases; injuries and intoxications; infectious and parasitic diseases; mental and behavioral disorders; skin and subcutaneous tissue disorders; neoplasms, carcinoma, and cancer), continues to be a deeply rooted practice in Mexico [1-3]. In this regard, one of these important plants is Justicia spicigera (known as "muicle" or "muitle"), an endemic plant from Mesoamerica that grows in Mexico, Central America, and some areas of the United States. In Mexico, it has been used since pre-Hispanic times to treat dysentery, gonorrhea, scabies, fever and uterine bleeding [4]. Currently, it is still used for medicinal purposes to treat cancer, circulatory diseases, diabetes, leukemia, anemia, giardiasis, fascioliasis, diarrhea, nerves, rheumatism, stomach inflammation and headache [4, 5]. Several research shows that the extract (aqueous, ethanolic and methanolic) of $J$. spicigera leaves have antioxidant [6], antimicrobial [7], anticancer [8], antidiabetic [9], antiepileptic [10], and antidepressant properties [11]. These properties are due to the presence, mainly of phenolic and flavonoids compounds. Justicia spicigera extracts contain significant concentrations of flavonoids, mainly kaempferol glycosides, the most important are: kaempferitrin (kaempferol-3,7-dirhamnoside) and astragalin (kaempferol-3- $\beta$-D-glucopyranoside), of which, it has been proven their antidiabetic [12, 13], and anticancer [3, 14] properties. Several studies [15-18], has been investigated the extraction of these compounds using different extraction methods (ultrasound-assisted extraction, ultrasound-microwaves, microwaves, and simple extraction). However, there is little information about the extraction of kaempferol and its glycosides from J. spicigera, using supercritical fluids.

The use of supercritical fluid technology (mainly $\mathrm{CO}_{2}$ ) to extract bioactive compounds from plant sources, is having a very important increase due to quality and purity of the obtained extracts, and because it is a technology 
that does not generate toxic waste. Furthermore, the process is performed at relatively low temperatures, in the absence of light and oxygen, which avoids degradation of labile compounds, as well as oxidative reactions [19]. One of the supercritical $\mathrm{CO}_{2}$ disadvantages is its low polarity (it behaves like a lipophilic solvent), which results in a minimum extraction of polar compounds, mainly phenols, flavonoids, and terpenoids. To increase the polarity and selectivity of supercritical $\mathrm{CO}_{2}$, the use of co-solvents (mainly ethanol due to its low toxicity) has been suggested for significantly improve the extraction of these polar compounds [20, 21]. However, it has been reported [22-24] that some phenolic and flavonoid compounds (gallic acid, protocatechuic acid, caffeic acid, methyl gallate, catechin, rutin, myrecitin, quercetin, kaempferol) are actually soluble in supercritical $\mathrm{CO}_{2}$ when pressures are high (above 200 bar), because fluid density increases, as the pressure increases at constant temperature. The aim of this work was to perform a study to obtain kaempferitrin and astragalin from J. spicigera by supercritical fluid $\mathrm{CO}_{2}$ extraction, using ethanol as co-solvent and compare it with conventional extraction. To the best of our knowledge, this is the first application of supercritical fluid extraction to extract and recovery these compounds from $J$. spicigera leaves.

\section{Materials and methods}

\subsection{Sample preparation}

Muicle leaves (J. spicigera) from the region of Cuautla, Morelos, Mexico were used (the leaves were harvested at the adult phase of the plant). The leaves were selected, washed, and dried at room temperature $\left(31 \pm 1^{\circ} \mathrm{C}\right.$, relative humidity of $75 \pm 7 \%$ ) until the moisture content was below $10 \%$. The dried leaves were ground in a stainless steel sprayer mill (Veyco MPV 100, Mexico) with a mesh of $0.5 \mathrm{~mm}$, the powder obtained was passed through a Tyler mesh 14 (1.4 mm opening sieve) and stored in sealed bags. The moisture content, water activity and average particle size were assessed.

\subsection{Moisture content}

It was measured according with the Mexican Official Standard [25]. The Sample was dehydrated at $100^{\circ} \mathrm{C}$ for $4 \mathrm{~h}$ in a convection oven (Boekel 107800, Boekel Industries Inc. Lower Southampton, PA, USA) at atmospheric pressure. The analysis was performed in triplicate.

\subsection{Water activity $\left(\mathrm{a}_{\mathrm{w}}\right)$}

It was measured using an AQUA-LAB hygrometer model 4TE (Decagon Devices Inc., Pullman, WA, USA) with internal temperature control $\left(15-50 \pm 0.2^{\circ} \mathrm{C}\right)$. The equipment was calibrated with standard solutions of $6.0 \mathrm{M}$ $\mathrm{NaCl}\left(\mathrm{a}_{\mathrm{w}}=0.76 \pm 0.003\right)$ and $8.57 \mathrm{M} \mathrm{LiCl}\left(\mathrm{a}_{\mathrm{w}}=0.50 \pm 0.003\right)$ at $25 \pm 0.1^{\circ} \mathrm{C}$. The analysis was performed in triplicate.

\subsection{Average particle size analysis}

The average particle size was performed using a particle analyzer with laser light diffraction Mastersizer 3000 (Malvern Instruments Limited, Worcestershire, UK) with a measuring range of 0.01 to $3500 \mu \mathrm{m}$. About 1 to 1.5 $\mathrm{g}$ of sample was used. The size distribution and cumulative weight curves were obtained, as well as the average diameter $d_{50}[26,27]$. The analysis was performed in triplicate.

\subsection{Supercritical fluid extraction (SFE)}

It was performed by using the SFE unit shown in Figure 1 (equipment designed in the lab). The sample $(5.01 \pm 0.01 \mathrm{~g})$ was placed in the sample-holder cell (9) and thereafter was placed in the extraction cell (10). The extraction cell was placed in a convection oven (12), the extraction temperature was set, and liquid $\mathrm{CO}_{2}$ and the co-solvent (ethanol $99.5 \%$ ) were pumped into extraction cell after the desired temperature was achieved. Once extraction conditions (pressure and temperature) were achieved, the recovery cell valve (16) was opened keeping a supercritical $\mathrm{CO}_{2}$ flow rate of $5 \mathrm{~mL} / \mathrm{min}$. The conditions were set as follows: pressure 200-300 bar, temperature $40-60^{\circ} \mathrm{C}$ and co-solvent flow rate of $0.5-1.0 \mathrm{~mL} / \mathrm{min}$. The extraction time was $180 \mathrm{~min}$ and at the end of this, liquid $\mathrm{CO}_{2}$ and ethanol were pumped through the SFE unit until co-solvent did not show extract residues. Preliminary tests were performed in order to specify the extraction time (Fig. 2). The extracts were placed in Erlenmeyer flasks with screw cap (capacity $125 \mathrm{~mL}$ ) covered with aluminum foil and kept at $-15^{\circ} \mathrm{C}$ until HPLC analysis. The volume and weight of the extracts were measured.

\subsection{Conventional extraction}

The conventional extraction method was performed using $2.52 \pm 0.01 \mathrm{~g}$ of sample, which was diluted with $50 \%$ (by mass) ethanol $(0.1 \mathrm{~g} / \mathrm{mL})$ to make $25 \mathrm{~mL}$ in a volumetric flask [28]. The solutions were placed in test tubes with screw cap (capacity $50 \mathrm{~mL}$ ) covered with aluminum. The extraction process was carried out using a $2 x 2$ factorial design, two temperatures (50 and $70^{\circ} \mathrm{C}$, in a water bath) and two extraction times (60 and $120 \mathrm{~min}$ ). 
During the extraction process, the solutions were shaken with a Vortex (G-560, Scientific Industries, Inc. Bohemia, N. Y. USA) at 15 min intervals [29]. The solutions were filtered through Whatman paper No. 4 and made up to a volume of $25 \mathrm{~mL}$ with distilled water. The extracts were placed in $50 \mathrm{~mL}$ flasks covered with aluminum foil and kept at $-15{ }^{\circ} \mathrm{C}$ until HPLC analysis. The extractions were performed in triplicate.

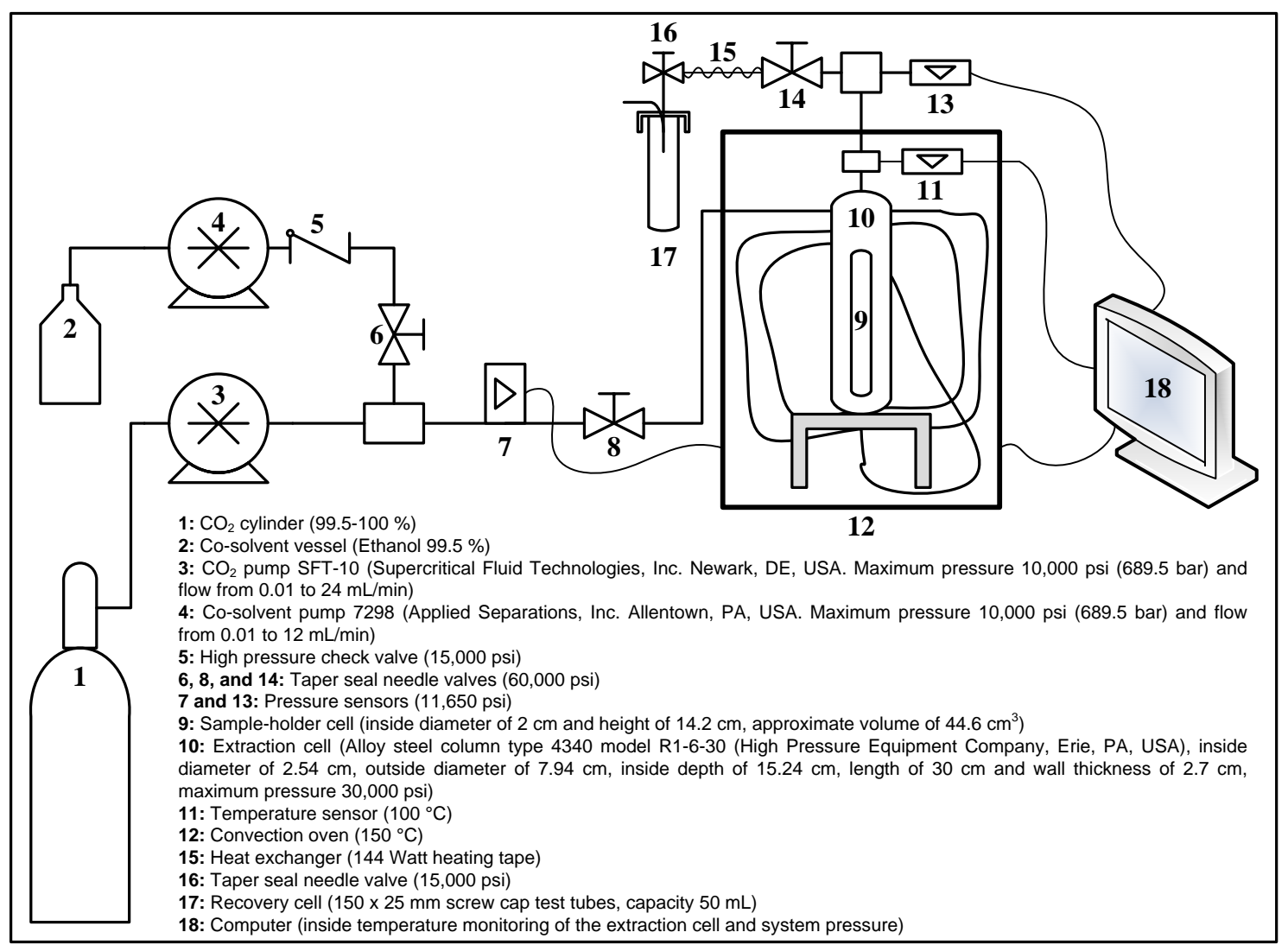

Figure 1. Schematic diagram of the supercritical fluid extraction (SFE) unit.

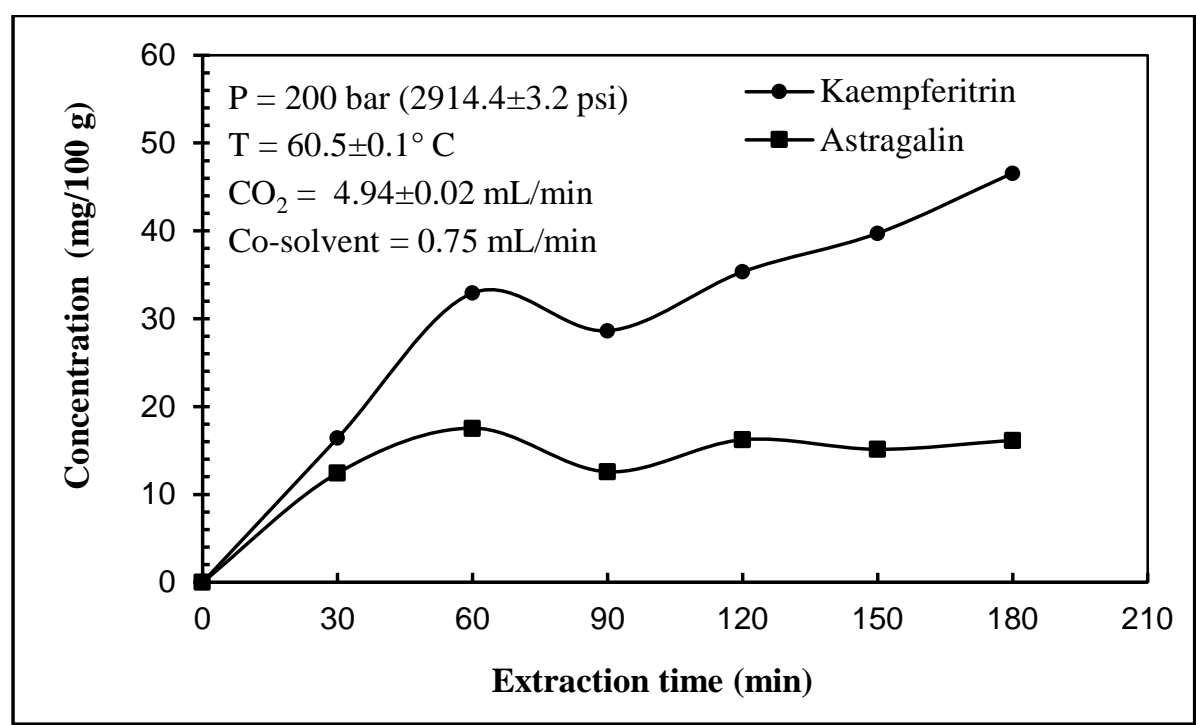

Figure 2. Kaempferitrin and astragalin concentration at different times by supercritical fluid $\mathrm{CO}_{2}$ extraction and ethanol as co-solvent.

\subsection{Identification and quantification of kaempferitrin (KM) and astragalin (KG) by HPLC analysis}

A volume of $1 \mathrm{~mL}$ of the extracts was taken and diluted with methanol (HPLC grade 99.96\%, JT Baker) to 10 $\mathrm{mL}$ in a volumetric flask. Afterward, diluted extracts were filtered through a $0.45 \mu \mathrm{m}$ membrane filter (Millipore) 
and transferred into $1.2 \mathrm{~mL}$ HPLC vials and capped. The HPLC analysis was performed using a Waters 1525 HPLC (Milford, MA, USA) equipped with a binary pump system, Waters 2487 dual absorbance detector (190 to $700 \mathrm{~nm}$ ) and Waters 717 autosampler (injection volume 0.1 to $2000 \mu \mathrm{L}$ ). A Dionex Acclaim ${ }^{\circledR} 120 \mathrm{C} 18$ column (150 $\mathrm{mm} \times 4.6 \mathrm{~mm}$ i. d.) packed with $5 \mu \mathrm{m}$ diameter particles was used. The extracts (10 and $200 \mu \mathrm{L})$ were eluted with acetic acid (A) (HPLC grade $\geq 99.7 \%$, JT Baker) at $2 \%$ and acetonitrile (B) (HPLC grade $99.98 \%$, JT Baker), at wavelength 265 and $368 \mathrm{~nm}$ [30], and according to the following elution gradient [31]: $90 \% \mathrm{~A}$ and 10 $\%$ B, 0 - 2.0 min (flow rate: $1.0 \mathrm{~mL} / \mathrm{min}$ ); $55 \% \mathrm{~A}$ and $45 \% \mathrm{~B}, 2.0$ - $6.4 \mathrm{~min}$ (flow rate: $1.0 \mathrm{~mL} / \mathrm{min}$ ); $45 \% \mathrm{~A}$ and $55 \%$ B, 6.5 - $7.0 \mathrm{~min}$ (flow rate: $1.0 \mathrm{~mL} / \mathrm{min}$ ); $30 \% \mathrm{~A}$ and $70 \% \mathrm{~B}, 7.1$ - $7.4 \mathrm{~min}$ (flow rate: $0.8 \mathrm{~mL} / \mathrm{min}$ ); $20 \%$ $\mathrm{A}$ and $80 \% \mathrm{~B}, 7.5$ - $8.0 \mathrm{~min}$ (flow rate: $0.2 \mathrm{~mL} / \mathrm{min}$ ); $30 \% \mathrm{~A}$ and $70 \% \mathrm{~B}, 8.1$ - $9.0 \mathrm{~min}$ (flow rate: $0.5 \mathrm{~mL} / \mathrm{min}$ ); $90 \% \mathrm{~A}$ and $10 \% \mathrm{~B}, 9.1$ - $16.0 \mathrm{~min}$ (flow rate: $1.0 \mathrm{~mL} / \mathrm{min}$ ). A volume of 10 and $200 \mu \mathrm{L}$ was injected of the conventional and supercritical fluid extracts, respectively. For quantification of KM (Kaempferol-3,7dirhamnoside $\geq 97 \%$, standard substance from Sigma) and KG (kaempferol-3- $\beta$-D-glucopyranoside $\geq 97 \%$, standard substance from Sigma), a solution (3 mL) was prepared with equal volumes $(1 \mathrm{~mL})$ of $\mathrm{KM}(0.28 \mathrm{mg} / \mathrm{mL})$ and $\mathrm{KG}(0.34 \mathrm{mg} / \mathrm{mL})$ using methanol (HPLC grade) as solvent. Of this solution, volumes of 2, 4, 6, 8 and $10 \mu \mathrm{L}$ were taken, equivalents to $0.19,0.37,0.56,0.75$ and $0.93 \mu \mathrm{g}$ for $\mathrm{KM}$ and $0.23,0.45,0.68,0.91$ and $1.13 \mu \mathrm{g}$ for $\mathrm{KG}$, respectively. Results were expressed as milligrams of KM or KG per $100 \mathrm{~g}$ of dry sample.

\subsection{Experimental design for optimization}

In order to determine the optimal conditions of extraction process and in accordance to several researches [24, 32-35], a $3^{3}$ Box-Behnken design without replicates (Table 1) was performed using response surface methodology (RSM), employing MINITAB® software. The independent variables were pressure (200-300 bar), extraction temperature $\left(40-60^{\circ} \mathrm{C}\right)$ and co-solvent flow rate $(0.5-1.0 \mathrm{~mL} / \mathrm{min}$, ethanol $99.5 \%)$, with a total 15 experiments including 3 central points. The extraction time and $\mathrm{CO}_{2}$ flow rate were kept constant $(180 \mathrm{~min}$ and $5 \mathrm{~mL} / \mathrm{min}$, respectively). The dependent variables were kaempferitrin (KM) and astragalin (KG) content. The experimental results were adjusted to a second-order polynomial model (Eq. 1):

$$
Y=\beta_{0}+\beta_{1} A+\beta_{2} B+\beta_{3} C+\beta_{4} A^{2}+\beta_{5} B^{2}+\beta_{6} C^{2}+\beta_{7} A B+\beta_{8} A C+\beta_{9} B C
$$

Where $Y$ is the predicted response; $A$ is the pressure; $B$ is the extraction temperature; $C$ is the co-solvent flow rate; $\beta_{0}$ is the intercept; $\beta_{1}, \beta_{2}, \beta_{3}$ are linear coefficients; $\beta_{4}, \beta_{5}, \beta_{6}$ are quadratic coefficients; $\beta_{7}, \beta_{8}, \beta_{9}$ are interaction coefficients. The model fit and the importance of the estimated parameters were determined by an analysis of variance (ANOVA). With the optimal conditions obtained in the supercritical extraction process (pressure, temperature, and co-solvent flow rate), the extraction of KM and KG was performed using $70 \%$ ethanol as cosolvent [33] in order to compare the yields with those obtained by pure ethanol (99.5\%), under the same conditions.

\subsection{Statistical analysis}

The effect of temperature and extraction time on the KM and KG content in conventional extracts of muicle, were analyzed by one-way analysis of variance (ANOVA) using Minitab (Release 17.1.0; Minitab Inc., State College, PA, USA). Differences were considered significant for values of $\mathrm{p} \leq 0.05$.

\section{Results and discussion}

\subsection{Granulometry and physic properties of powdered Justicia spicigera leaves}

The granulometric distribution analysis of the powdered muicle leaves (J. spicigera) used for obtaining extracts, had an average diameter $\left(d_{50}\right)$ of $638.3 \pm 76.9 \mathrm{~mm}$, with a moisture of $7.86 \pm 0.22 \%$ and $\mathrm{a}_{\mathrm{w}}$ of $0.53 \pm 0.02$.

\subsection{Evaluation of the models' suitability}

The results of all Box-Behnken design experiments are shown in Table 1. In the first evaluation, the analysis was performed considering all the terms of the mathematical model (Eq. 1). The quadratic term, the linear term and the cross-product terms between the pressure $(A)$, extraction temperature $(B)$ and co-solvent flow rate $(C)$, were considered statistically significant $(\mathrm{p} \leq 0.05)$. In order to get a better model, only the significant terms were included in the model [36].

Table 2 shows the regression parameters for each response variable. It can be observed that the analysis of variance was statistically significant for the two models and the lack of fit was not significant $(p>0.05)$, which indicates that the models could be adjusted properly to the experimental data. With respect to the coefficient of determination $\left(\mathrm{R}^{2}\right)$, commonly is used to explain the overall predictive capability of the model. The values obtained from $\mathrm{R}^{2}$ were 0.755 and 0.876 , which indicates the models fit well to the experimental data since values higher than 0.75 indicates aptness of the model [37]. However, a value close to 1 of $\mathrm{R}^{2}$ does not necessarily imply that the regression model be suitable, since adding a variable to the model will always increase $\mathrm{R}^{2}$, regardless of 
whether the additional variable is statistically significant or not. Therefore, it is possible for models that have large values of $\mathrm{R}^{2}$ to yield poor predictions of new observations or estimates of the mean response [38].

Table 1. Box-Behnken design and experimental data for the content of kaempferitrin (KM) and astragalin (KG).

\begin{tabular}{|c|c|c|c|c|c|}
\hline \multirow[b]{2}{*}{ Run } & \multicolumn{3}{|c|}{ Independent variables } & \multicolumn{2}{|c|}{ Dependent variables } \\
\hline & $\begin{array}{l}\text { Pressure } \\
\text { (bar) }\end{array}$ & $\begin{array}{c}\text { Temperature } \\
\left({ }^{\circ} \mathrm{C}\right)\end{array}$ & $\begin{array}{c}\text { Co-solvent flow rate } \\
\text { (mL/min) }\end{array}$ & $\begin{array}{c}\mathrm{KM} \\
(\mathrm{mg} / 100 \mathrm{~g})\end{array}$ & $\begin{array}{c}\mathrm{KG} \\
(\mathrm{mg} / 100 \mathrm{~g})\end{array}$ \\
\hline 1 & 250 & 60 & 0.50 & 8.37 & 5.61 \\
\hline 2 & 200 & 50 & 1.00 & 110.10 & 31.49 \\
\hline 3 & 300 & 50 & 1.00 & 109.98 & 26.43 \\
\hline 4 & 250 & 60 & 1.00 & 76.52 & 30.29 \\
\hline 5 & 250 & 50 & 0.75 & 28.90 & 10.69 \\
\hline 6 & 250 & 50 & 0.75 & 55.04 & 17.64 \\
\hline 7 & 300 & 40 & 0.75 & 73.35 & 19.90 \\
\hline 8 & 250 & 40 & 0.50 & 10.23 & 6.47 \\
\hline 9 & 200 & 40 & 0.75 & 103.07 & 37.86 \\
\hline 10 & 250 & 40 & 1.00 & 45.84 & 18.45 \\
\hline 11 & 300 & 60 & 0.75 & 94.97 & 45.30 \\
\hline 12 & 250 & 50 & 0.75 & 64.54 & 24.26 \\
\hline 13 & 200 & 50 & 0.50 & 26.69 & 19.16 \\
\hline 14 & 200 & 60 & 0.75 & 52.68 & 27.52 \\
\hline 15 & 300 & 50 & 0.50 & 10.17 & 13.82 \\
\hline
\end{tabular}

Table 2. Analysis of variance of the regression parameters of the predicted response surface quadratic models.

\begin{tabular}{|c|c|c|c|c|c|c|c|c|c|c|}
\hline \multirow{3}{*}{$\begin{array}{l}\text { Source of } \\
\text { variation }\end{array}$} & \multicolumn{10}{|c|}{ Dependent variable } \\
\hline & \multicolumn{5}{|c|}{ Kaempferitrin (KM) } & \multicolumn{5}{|c|}{ Astragalin (KG) } \\
\hline & DF & SS & MS & F-Value & $p$-Value & DF & SS & MS & F-Value & $p$-Value \\
\hline Model & 4 & 13949.1 & 3487.3 & 7.69 & 0.004 & 6 & 1537.13 & 256.19 & 9.40 & 0.003 \\
\hline Linear & 3 & 10297.1 & 3432.4 & 7.57 & 0.006 & 3 & 572.80 & 190.93 & 7.01 & 0.013 \\
\hline$A$ & 1 & 2.1 & 2.1 & 0.00 & 0.948 & 1 & 13.99 & 13.99 & 0.51 & 0.494 \\
\hline$B$ & 1 & 0.0 & 0.0 & 0.00 & 0.999 & 1 & 84.73 & 84.73 & 3.11 & 0.116 \\
\hline C & 1 & 10295.1 & 10295.1 & 22.72 & 0.001 & 1 & 474.08 & 474.08 & 17.40 & 0.003 \\
\hline Quadratic & 1 & 3651.9 & 3651.9 & 8.06 & 0.018 & 2 & 644.95 & 322.48 & 11.83 & 0.004 \\
\hline$A^{2}$ & 1 & 3651.9 & 3651.9 & 8.06 & 0.018 & 1 & 451.32 & 451.32 & 16.56 & 0.004 \\
\hline$C^{2}$ & - & - & - & - & - & 1 & 152.82 & 152.82 & 5.61 & 0.045 \\
\hline Interactions & - & - & - & - & - & 1 & 319.38 & 319.38 & 11.72 & 0.009 \\
\hline$A B$ & - & - & - & - & - & 1 & 319.38 & 319.38 & 11.72 & 0.009 \\
\hline Error & 10 & 4532.2 & 453.2 & & & 8 & 218.02 & 27.25 & & \\
\hline Lack of fit & 8 & 3850.8 & 481.4 & 1.41 & 0.479 & 6 & 125.90 & 20.98 & 0.46 & 0.807 \\
\hline Pure error & 2 & 681.4 & 340.7 & & & 2 & 92.12 & 46.06 & & \\
\hline Total & 14 & 18481.3 & & & & 14 & 1755.15 & & & \\
\hline $\mathrm{R}^{2}$ & & & 0.7548 & & & & & 0.875 & & \\
\hline $\mathrm{R}_{\mathrm{adj}}{ }$ & & & 0.6567 & & & & & 0.782 & & \\
\hline $\mathrm{R}_{\text {pred }}^{2}$ & & & 0.4209 & & & & & 0.611 & & \\
\hline APV & & & 4.88 & & & & & 7.53 & & \\
\hline AAD & & & 11.87 & & & & & 4.77 & & \\
\hline PRESS & & & 9702.52 & & & & & 681.33 & & \\
\hline
\end{tabular}

$A=$ Pressure. $B=$ Temperature. $C=$ Co-solvent flow rate. $\mathrm{DF}=$ Degrees of freedom. $\mathrm{SS}=$ Sum of squares. MS = Mean square. $\mathrm{R}^{2}=$ Coefficient of determination. $\mathrm{R}^{2}{ }_{\text {adj }}=$ Adjusted determination coefficient. $\mathrm{R}^{2}$ pred $=$ Predicted determination coefficient. APV = Adequate precision value. AAD = Absolute average deviation. PRESS = Predicted residual error of sum of square.

Values of $\mathrm{R}^{2}$ close to 1 and an AAD (absolute average deviation) as small as possible indicate that the model equation defines the true behavior of the system and it can be used for interpolation in the experimental domain $[36,39]$. Moreover, the APV (adequate precision value) is an index of the signal to noise ratio and a value greater than 4 is an essential requirement for a model to be a good fit [37]. According to Myers et al. [38] if $\mathrm{R}^{2}$ and $\mathrm{R}^{2}$ adj differ substantially, there is a strong possibility that nonsignificant terms have been included in the model. In 
accordance with the results obtained for $\mathrm{R}^{2}$, AAD (11.87 and 4.77) and APV (4.88 and 7.53), the equations of the models (2 and 3) satisfied the aforementioned thus the concentration of kaempferitrin and astragalin in muicle can be expressed in terms of the following regression equations:

$$
\begin{gathered}
K M=718.0-6.27(A)-0.001(B)+143.5(C)+0.0125\left(A^{2}\right) \\
K G=428.4-3.125(A)-4.14(B)+184.7(C)+0.0044\left(A^{2}\right)-102.6\left(C^{2}\right)+0.0179(A B)
\end{gathered}
$$

\subsection{Extraction process optimization}

The regression models allowed predictions of the effects of independent variables on the kaempferitrin (KM) and astragalin (KG) yields from muicle (J. spicigera). The relationship between independent and dependent variables is shown in the three-dimensional representation of the response surfaces generated by the models (Fig. 3). A significant effect $(\mathrm{p} \leq 0.05)$ between pressure and temperature (Fig. 3d) was observed on the KG yields, by increasing pressure and extraction temperature, highest concentrations are achieved. In the case of KM yields (Fig. 3a), no significant effect was observed. Regarding pressure and co-solvent flow rate (Fig. 3b and 3e), no significant effect on the KM and KG yields was observed. However, a positive correlation between pressure and co-solvent flow rate can be observed. The same has occurred with the temperature and co-solvent flow rate interaction (Fig. 3c and 3f). Furthermore, it can be observed that the KM and KG yields are the same at pressures of 200 and 300 bar at different co-solvent flow rates (Fig. 3b and 3e). The most influential factor from regression models (Eqs. 2 and 3) was the co-solvent flow rate.

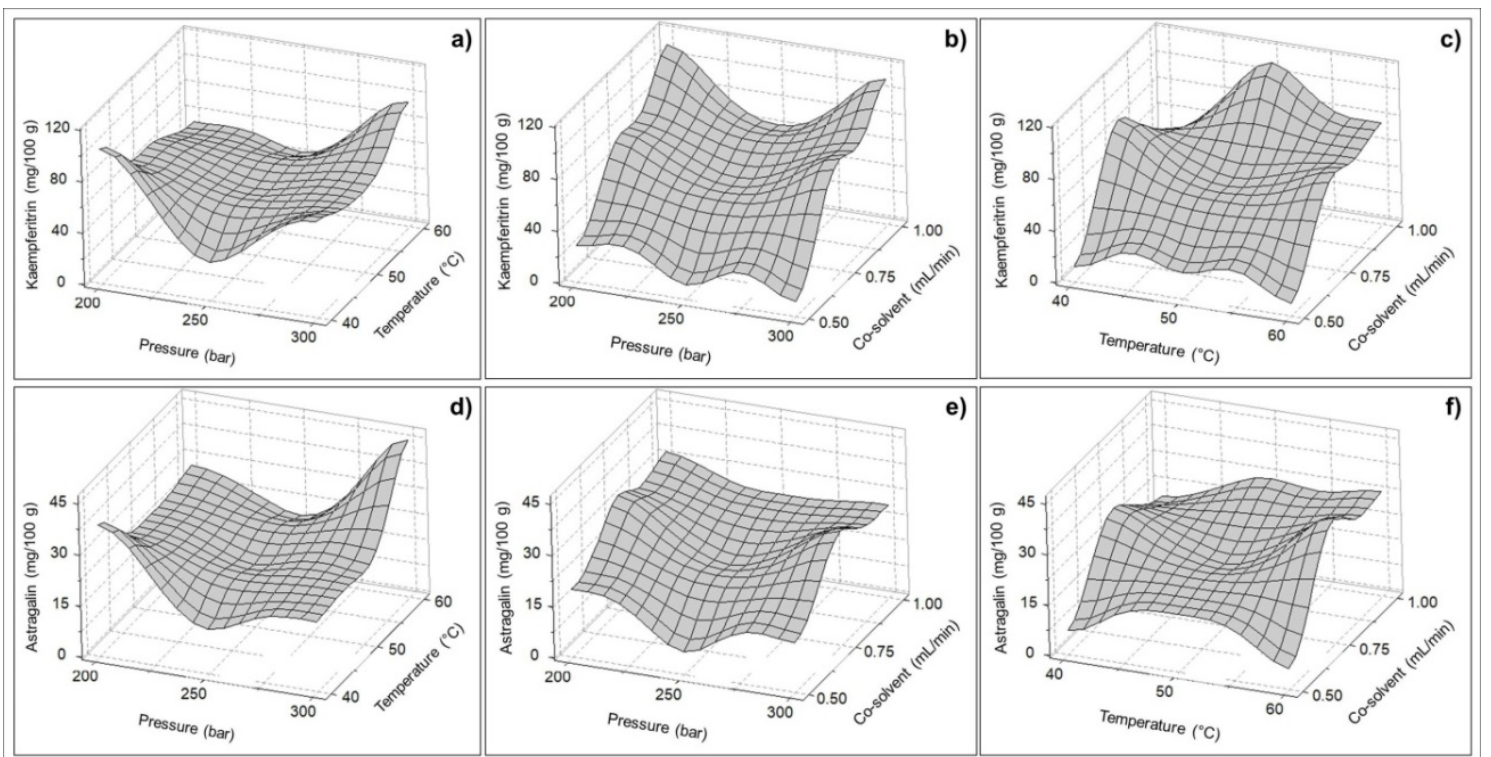

Figure 3. Response surface graphs for kaempferitrin and astragalin content (experimental data) as a function of pressure, temperature, and co-solvent flow rate.

In general, a similar behavior can be observed between KM and KG concentration with regard to independent variables. This was confirmed by obtaining a positive correlation (Fig. 4) between KM and KG concentrations, therefore the extraction conditions showed a similar effect in both compounds.

Overall, higher yields showed a tendency toward high pressures, high temperatures, and high co-solvent flow rates. The foregoing differs from that reported by Liza et al. [34] who concluded that the pressure had a higher influence on the yield in the extraction of Strobilanthes crispus leaves, using supercritical $\mathrm{CO}_{2}$ and ethanol (99.5 $\%)$ as co-solvent. The best conditions were at pressure $200 \mathrm{bar}$, temperature $50^{\circ} \mathrm{C}$ and time $60 \mathrm{~min}$, keeping the flow rates of $\mathrm{CO}_{2}$ and ethanol constant ( $10 \mathrm{y} 1 \mathrm{~g} / \mathrm{min}$, respectively). Eight flavonoids were identified in the extract obtained (3.98 \% total flavonoids) with the optimal conditions, of which the highest concentration was kaempferol (19.45 mg/g). Similar results were obtained by Wang et al. [35] using supercritical $\mathrm{CO}_{2}$ to obtain bioactive compounds from Ampelopsis grossedentata stems. Highest content of total flavonoids (4.67 $\pm 0.36 \mathrm{mg}$ routine equivalents/g dry sample) and total phenols (2.49 $\pm 0.10 \mathrm{mg}$ gallic acid equivalents/g dry sample) were obtained at $250 \mathrm{bar}, 40^{\circ} \mathrm{C}, 50 \mathrm{~min}$, with a ratio methanol:ethanol of 1:3 for total flavonoids and 1:1 for total phenols. Authors conclude that by decreasing supercritical $\mathrm{CO}_{2}$ density, influences extraction more, than increasing vapor pressure of solute.

On the other hand, Li et al. [33] implemented the response surface methodology to obtain two kaempferol glycosides, KG1 (kaempferol-3-O-[2-O- $\beta$-D-galactopyranosyl-6-O- $\alpha$-L-rhamnopyranosyl]- $\beta$-D- 
glucopyranoside) and KG2 (kaempferol-3-O-[2-O- $\beta$-D-xylopyranosyl-6-O- $\alpha$-L-rhamnopyranosyl]- $\beta$-Dglucopyranoside), from tea seed cake of Camellia sinensis (by-product produced by pressing the seeds of green tea during traditional processing to obtain oil), by supercritical fluid extraction. The optimal conditions were: extraction time $150 \mathrm{~min}$, pressure $20 \mathrm{MPa}\left(200 \mathrm{bar}\right.$ ), temperature $80^{\circ} \mathrm{C}$ and $60 \%$ ethanol. The flow rates of $\mathrm{CO}_{2}$ and the co-solvent was maintained at $2 \mathrm{~L} / \mathrm{min}$ and $0.5 \mathrm{~mL} / \mathrm{min}$, respectively. Authors conclude that higher yields were correlated with lower pressures and with the increase in temperature, probably due to the higher speed of mass transfer.

According to response surface analysis, the highest concentration of KM (109.0 mg/100 g dry powder) was achieved at $300 \mathrm{bar}, 60^{\circ} \mathrm{C}$, and a co-solvent flow rate of $1.0 \mathrm{~mL} / \mathrm{min}$. In the case of $\mathrm{KG}$, the highest concentration (44.07 mg/100 g of dry powder) was achieved at $300 \mathrm{bar}, 60^{\circ} \mathrm{C}$, and a co-solvent flow rate of $0.9 \mathrm{~mL} / \mathrm{min}$. Under these conditions ( $300 \mathrm{bar}, 60^{\circ} \mathrm{C}$, and a co-solvent flow rate of $1.0 \mathrm{~mL} / \mathrm{min}$, with an extraction time of $180 \mathrm{~min}$ and a $\mathrm{CO}_{2}$ flow rate of $5 \mathrm{~mL} / \mathrm{min}$ ), extractions were performed (in triplicate), and concentrations obtained for $\mathrm{KM}$ and KG were $115.08 \pm 2.81$ and $56.63 \pm 9.02 \mathrm{mg} / 100 \mathrm{~g}$ of dry powder, respectively. Comparing the calculated values with the experimental ones by using a t-test, there were no significant differences, therefore the quadratic models are suitable.

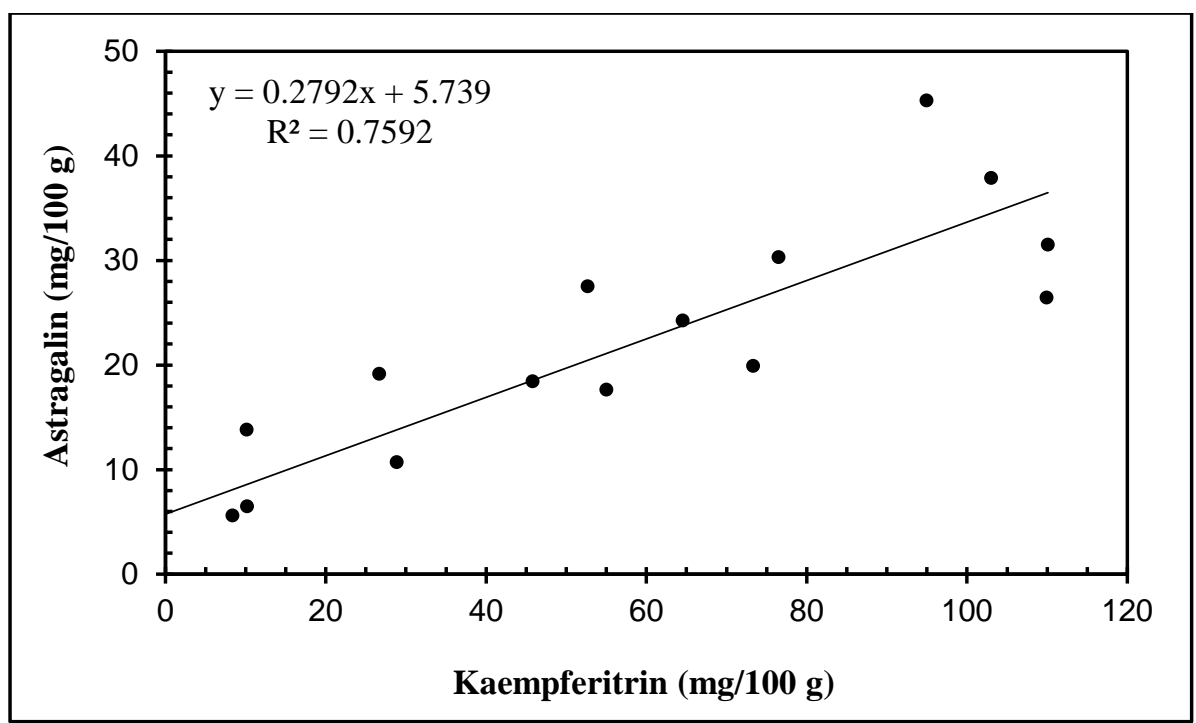

Figure 4. The Relationship between kaempferitrin and astragalin concentration in muicle (J. spicigera) extracts obtained by supercritical fluids.

\subsection{Comparison of extraction methods}

The effect of temperature and extraction time on the KM and KG yields in muicle extracts obtained by the conventional method are shown in Table 3. It can be observed that the higher the temperature and the higher the extraction time, the higher the yields of KM and KG. Treatment 4 showed the highest yields of KM and KG (574.20 \pm 65.10 and $113.10 \pm 15.06 \mathrm{mg} / 100 \mathrm{~g}$ of dry powder, respectively). These results are higher than those obtained by supercritical extraction under optimal conditions $(115.08 \pm 2.81$ and $56.63 \pm 9.02 \mathrm{mg} / 100 \mathrm{~g}$ of dry powder, respectively), equivalent to 20 and $50 \%$ of KM and KG, respectively; compared to the yields obtained in conventional extraction for treatment 4.

Table 3. Effect of temperature and extraction time on kaempferitrin (KM) and astragalin (KG) yields in muicle extracts obtained by conventional extraction.

\begin{tabular}{ccccc}
\hline Treatment & Temperature $\left({ }^{\circ} \mathbf{C}\right)$ & Time (min) & KM (mg/100 g) & KG (mg/100 g) \\
\hline 1 & 50 & 60 & $348.20 \pm 25.90 \mathrm{a}$ & $59.74 \pm 7.50$ a \\
2 & 50 & 120 & $461.18 \pm 5.02 \quad \mathrm{~b}$ & $80.24 \pm 9.15$ a \\
3 & 70 & 60 & $477.60 \pm 36.82 \mathrm{bc}$ & $61.20 \pm 8.84$ a \\
4 & 70 & 120 & $574.20 \pm 65.10 \mathrm{c}$ & $113.85 \pm 15.20 \mathrm{~b}$ \\
\hline
\end{tabular}

Values represent the mean \pm standard deviation of three observations. Values bearing different letters in the same column are significantly different $(\mathrm{p} \leq 0.05)$.

Because these flavonols contain sugar molecules in their structure, this makes them more soluble in aqueous solutions of ethanol, than in pure ethanol, due to the hydroxyl groups [29, 40]. Therefore, new extractions (in 
triplicate) were performed, using $70 \%$ (by mass) ethanol as co-solvent and according to the optimal conditions achieved in the response surface analysis (300 bar, $60{ }^{\circ} \mathrm{C}$, and a co-solvent flow rate of $1.0 \mathrm{~mL} / \mathrm{min}$ ). The results showed a higher concentration of KM and KG $(562.71 \pm 156.85$ and $79.90 \pm 18.03 \mathrm{mg} / 100 \mathrm{~g}$ of dry powder, respectively) compared to the $99.5 \%$ ethanol extractions. The use of $70 \%$ ethanol as co-solvent in the supercritical extraction process considerably improved the yields of KM and KG (98.0 and $70.0 \%$, respectively, compared to the yields obtained in conventional extraction for treatment 4). Figure 5 shows the chromatograms obtained for the standards (kaempferitrin and astragalin), the muicle extracts (J. spicigera) obtained by supercritical fluids, and the conventional extraction.

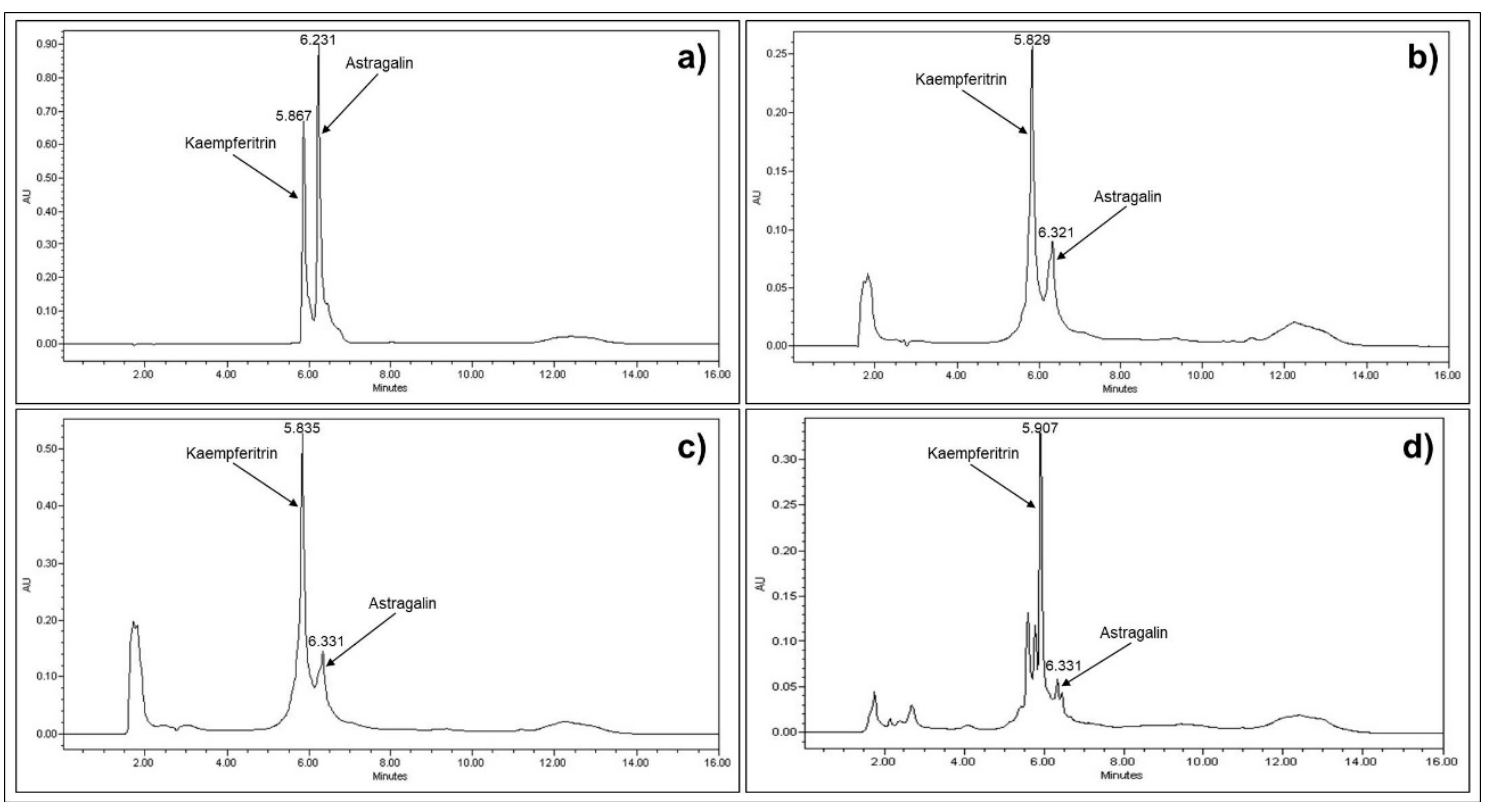

Figure 5. Chromatograms obtained by HPLC at $265 \mathrm{~nm}$. a) Standards solution. b) Muicle extract obtained with the optimal conditions by supercritical fluids ( $99.5 \%$ ethanol as co-solvent). c) Muicle extract obtained with the optimal conditions by supercritical fluids (70 \% ethanol as co-solvent). d) Muicle extract obtained by conventional extraction $\left(70^{\circ} \mathrm{C}\right.$ and $\left.120 \mathrm{~min}\right)$.

\section{Conclusions}

Adequate fits were achieved and most of the variability of the responses was explained by the models obtained. Supercritical fluid extraction of KM and KG from muicle (J. spicigera), was optimized at $300 \mathrm{bar}, 60^{\circ} \mathrm{C}$, and $1.0 \mathrm{~mL} / \mathrm{min}$ of co-solvent flow rate, with a constant $\mathrm{CO}_{2}$ flow rate of $5 \mathrm{~mL} / \mathrm{min}$ and extraction time of $180 \mathrm{~min}$. In accordance with the KM and KG concentration, the most influential variable was the co-solvent flow rate. Moreover, a positive correlation could be observed between KM and KG concentration, suggesting that the extraction conditions showed a similar effect in both compounds. The use of $70 \%$ ethanol as co-solvent significantly improved the yields of KM and KG, compared to pure ethanol. Adequate yields were achieved of KM and KG by supercritical fluid extraction compared with conventional extraction (98 and $70 \%$, respectively). However, it is recommended to perform extractions at different concentrations of ethanol aqueous solutions as cosolvent, with the aim of increasing KM and KG yields. Taking into account the functional properties of these flavonols (kaempferitrin and astragalin), J. spicigera extracts obtained by supercritical fluids could be used in the development of functional foods, as well as its possible use in traditional medicine by the health professionals.

\section{References}

[1] Cruz-Pérez AL, Barrera-Ramos J, Bernal-Ramírez LA, Bravo-Avilez D, Rendón-Aguilar B. Actualized inventory of medicinal plants used in traditional medicine in Oaxaca, Mexico. Journal of Ethnobiology and Ethnomedicine. 2021; 17(1):1-15. https://doi.org/10.1186/s13002-020-00431-y.

[2] Jasso-Gándara SN, Estrada-Castillón E, Encina-Domínguez JA, Villarreal-Quintanilla, JÁ, Arévalo-Sierra JR. Plants used as medicinal in Güémez, Tamaulipas, north-eastern Mexico. Notulae Botanicae Horti Agrobotanici Cluj-Napoca. 2020;48(3):1130-1140. https://doi.org/10.15835/nbha48311955.

[3] Fernández-Pomares C, Juárez-Aguilar E, Domínguez-Ortiz MA, Gallegos-Estudillo J, Herrera-Covarrubias D, Sánchez-Medina A, Aranda-Abreu GE, Manzo J, Hernández ME. Hydroalcoholic extract of the widely 
used Mexican plant Justicia spicigera Schltdl. exerts a cytostatic effect on LNCaP prostate cancer cells. Journal of Herbal Medicine. 2018;12:66-72. https://doi.org/10.1016/j.hermed.2017.09.003.

[4] Baqueiro-Peña I, Guerrero-Beltrán JA. Uses of Justicia spicigera in medicine and as a source of pigments. Functional Foods in Health and Disease. 2014;4:401-414.

[5] Gomez-Verjan JC, Reyes-Chilpa R, Aguilar MI. Chemistry and pharmacology of selected Asian and American medicinal species of Justicia. In: Gupta VK, editor. Bioactive phytochemicals: Perspectives for modern medicine Vol. 1. New Delhi: Daya Publishing House; 2013. p. 400-418.

[6] Awad NE, Abdelkawy MA, Abdelrahman EH, Hamed MA, Ramadan NS. Phytochemical and in vitro Screening of Justicia spicigera Ethanol Extract for Antioxidant Activity and in vivo Assessment Against Schistosoma mansoni Infection in Mice. Anti-Infective Agents. 2018;16(1): 49-56. https://doi.org/ 10.2174/2211352516666180126161247.

[7] Bernardo-Mazariegos E, Valdez-Salas B, González-Mendoza D, Abdelmoteleb A, Tzintzun-Camacho O, Ceceña-Duran C, Gutiérrez-Miceli F. Silver nanoparticles from Justicia spicigera and their antimicrobial potentialities in the biocontrol of foodborne bacteria and phytopathogenic fungi. Revista Argentina de microbiología. 2019;51(2): 103-109. https://doi.org/10.1016/j.ram.2018.05.002

[8] Alonso-Castro AJ, Ortiz-Sánchez E, Domínguez F, Arana-Argáez V, Juárez-Vázquez MC, Chávez M, et al. Antitumor and immunomodulatory effects of Justicia spicigera Schltdl (Acanthaceae). Journal of Ethnopharmacology. 2012;141:888-894. https://doi.org/10.1016/j.jep.2012.03.036.

[9] Escandón-Rivera SM, Mata R, Andrade-Cetto A. Molecules isolated from Mexican hypoglycemic plants: A Review. Molecules. 2020;25(18):4145. http://doi.org/ 10.3390/molecules25184145.

[10] González-Trujano ME, Domínguez F, Pérez-Ortega G, Aguillón M, Martínez-Vargas D, Almazán-Alvarado S, Martínez A. Justicia spicigera Schltdl. and kaempferitrin as potential anticonvulsant natural products. Biomedicine \& Pharmacotherapy. 2017;92:240-248. http://doi.org/10.1016/j.biopha.2017.05.075.

[11] Cassani J, Dorantes-Barrón AM, Novales LM, Real GA, Estrada-Reyes R. Anti-depressant-like effect of kaempferitrin isolated from Justicia spicigera Schltdl (Acanthaceae) in two behavior models in mice: evidence for the involvement of the serotonergic system. Molecules. 2014;19:21442-21461. https://doi.org/10.3390/molecules191221442.

[12] Da Silva D, Marques-Casanova L, Celestino-Marcondes M, Espindola-Netto JM, Pereira-Paixão L, OliveiraDe Melo G, Zancan P, Sola-Penna M, Soares-Costa S. Antidiabetic Activity of Sedum dendroideum: Metabolic enzymes as putative targets for the bioactive flavonoid kaempferitrin. International Union of Biochemistry and Molecular Biology. 2014;66:361-370. https://doi.org/10.1002/iub.1270.

[13] Nazira-Sarian M, Uddin-Ahmed Q, Mat-So’ad SZ, Muhammad-Alhassan A, Murugesu S, Perumal V. Antioxidant and antidiabetic effects of flavonoids: A structure-activity relationship based study. BioMed Research International. 2017:8386065. https://doi.org/10.1155/2017/8386065.

[14] Alonso-Castro AJ, Ortiz-Sánchez E, García-Regalado A, Ruiz G, Núñez-Martínez JM, González-Sánchez I, Quintanar-Jurado V, Morales-Sánchez E, Dominguez F, López-Toledo G, Cerbón MA, García-Carrancá A. Kaempferitrin induces apoptosis via intrinsic pathway in HeLa cells and exerts antitumor effects. Journal of Ethnopharmacology. 2013;145:476-489. http://doi.org/10.1016/j.jep.2012.11.016.

[15] Castro-Alatorre NC, Gallardo-Velázquez T, Boyano-Orozco LC, Téllez-Medina DI, Meza-Márquez OG, Osorio-Revilla G. Extraction and Microencapsulation of Bioactive Compounds from Muicle (Justicia spicigera) and Their Use in the Formulation of Functional Foods. Foods. 2021;10(8):1747. https://doi.org/10.3390/foods10081747.

[16] Goktas S, Köse MD, Bayraktar O, A. Screening experimental design to develop high extraction yield of flavonoids in Ginkgo biloba leaves. Journal of Pharmaceutical and Applied Chemistry. 2017;3(1):33-39. http://doi.org/10.18576/jpac/030104.

[17] Savic IM, Nikolic VD, Savic-Gajic IM, Nikolic LjB, Moder K, Hopkins M. Optimization of quercetin extraction from green tea (Camellia sinensis) using central composite design, and the pharmacological activity of the extract. Chem Biochem Eng Q. 2016;30:103-115. http://doi.org/10.15255/CABEQ.2015.2166.

[18] Biba O, Strnad M, Cruz J. Analytical approaches for kaempferol determination. In: Villers G, Fougere Y, editors. Kaempferol. Chemistry, natural occurrences and health benefits. New York: Nova Science Publishers, Inc.; 2013. pp 97-147.

[19] Beckman EJ. Supercritical and near-critical $\mathrm{CO}_{2}$ in green chemical synthesis and processing. Journal of Supercritical Fluids. 2004;28:121-191. https://doi.org/10.1016/S0896-8446(03)00029-9.

[20] Yang C, Yan-Rong X, Wei-Xi Y. Extraction of pharmaceutical components from Ginkgo biloba leaves using supercritical carbon dioxide. Journal of Agricultural and Food Chemistry. 2002;50:846-849. https://doi.org /10.1021/jf010945f.

[21] Chafer A, Fornari T, Berna A, Stateva RP. Solubility of quercetin in supercritical $\mathrm{CO}_{2}+$ ethanol as a modifier: measurements and thermodynamic modeling. Journal of Supercritical Fluids. 2004;32:89-96. https://doi.org/10.1016/j.supflu.2004.02.005. 
[22] Murga R, Sanz MT, Beltrán S, Cabezas JL. Solubility of some phenolic compounds contained in grape seeds, in supercritical carbon dioxide. Journal of Supercritical Fluids. 2002;23:113-121. https://doi.org/10.1016/ S0896-8446(02)00033-5.

[23] Bimakr M, Rahman RA, Taip FS, Ganjloo A, Salleh LM, Selamat J, Hamid A, Zaidul ISM. Comparison of different extraction methods for the extraction of major bioactive flavonoid compounds from spearmint (Mentha spicata L.) leaves. Food and Bioproducts Processing. 2011;89:67-72. https://doi.org/10.1016 /j.fbp.2010.03.002.

[24] Sanjaya RE, Tedjo YY, Kurniawan A, Ju YH, Ayucitra A, Ismadji S. Investigation on supercritical $\mathrm{CO}_{2}$ extraction of phenolic-phytochemicals from an epiphytic plant tuber (Myrmecodia pendans). Journal of $\mathrm{CO}_{2}$ Utilization. 2014;6:26-33. https://doi.org/10.1016/j.jcou.2014.03.001.

[25] NOM-116-SSA1-1994. Mexican standard. Determination of moisture in foods by heat treatment. Method for sand or gauze. 1994 (in Spanish). Available from: http://www.salud.gob.mx/unidades/cdi/nom/ 116ssa14.html

[26] O’Hagan P, Hasapidis K, Coder A, Helsing H, Pokrajac G. Particle size analysis of food powders. In: Onwulata C, editor. Encapsulated and powdered foods. Boca Raton FL: CRC Press Taylor \& Francis Group; 2005. pp 215-245.

[27] Barbosa-Cánovas GV, Ortega-Rivas E, Juliano P, Yan H. Food powders. Physical properties, processing, and functionality. Kluwer Academic/Plenum Publishers, New York. 2005.

[28] Naeem S, Ali M, Mahmood A. Optimization of extraction conditions for the extraction of phenolic compounds from Moringa oleifera leaves. Pakistan Journal of Pharmaceutical Sciences. 2012;25(3):535-541.

[29] Jokić S, Velić D, Bilić M, Bucić-Kojić A, Planinić M, Tomas S. Modelling of the process of solid-liquid extraction of total polyphenols from soybeans. Czech Journal of Food Sciences. 2010;28(3):206-212. https://doi.org/10.17221/200/2009-CJFS.

[30] Zu Y, Li C, Fu Y, Zhao C. Simultaneous determination of catechin, rutin, quercetin, kaempferol and isorhamnetin in the extract of sea buckthorn (Hippophae rhamnoides L.) leaves by RP-HPLC with DAD. Journal of Pharmaceutical and Biomedical Analysis. 2006;41:714-719. https://doi.org/10.1016/ j.jpba.2005.04.052.

[31] Delgado-Flores ML. Characterization and quantification of flavonoids in two Petroselinum species with different heat treatments. [MSc Thesis]. Monterrey, Nuevo León, México: Facultad de Salud Pública y Nutrición. Universidad Autónoma de Nuevo León. 2015 (in Spanish).

[32] Leal PF, Maia NB, Carmello QAC, Catharino RR, Eberlin MN, Meireles MAA. Sweet basil (Ocimum basilicum) extracts obtained by supercritical fluid extraction (SFE): Global yields, chemical composition, antioxidant activity, and estimation of the cost of manufacturing. Food and Bioprocess Technology. 2008;1:326-338. https://doi.org/10.1007/s11947-007-0030-1

[33] Li B, Xu Y, Yu-Xia J, Yuan-Yuan W, You-Ying T. Response surface optimization of supercritical fluid extraction of kaempferol glycosides from tea seed cake. Industrial Crops and Products. 2010;32:123-128. https://doi.org/10.1016/j.indcrop.2010.04.002.

[34] Liza MS, Rahman RA, Mandana B, Jinap S, Rahmat A, Zaidul ISM, Hamid A. Supercritical carbon dioxide extraction of bioactive flavonoid from Strobilanthes crispus (Pecah Kaca). Food and Bioproducts Processing. 2010;88:319-326. https://doi.org/10.1016/j.fbp.2009.02.001.

[35] Wang Y, Ying L, Sun D, Zhang S, Zhu Y, Xu P. Supercritical carbon dioxide extraction of bioactive compounds from Ampelopsis grossedentata stems: Process optimization and antioxidant activity. International Journal of Molecular Sciences. 2011;12:6856-6870. https://doi.org/10.3390/ijms12106856.

[36] Yolmeh M, Jafari SM. Applications of response surface methodology in the food industry Processes. Food and Bioprocess Technology. 2017;10(3):413-433. https://doi.org/10.1007/s11947-016-1855-2.

[37] Chauhan B, Gupta R. Application of statistical experimental design for optimization of alkaline protease production from Bacillus sp. RGR-14. Process Biochem. 2004;39:2115-2122. https://doi.org/10.1016/ j.procbio.2003.11.002.

[38] Myers RH, Montgomery DC, Anderson-Cook CM. Response surface methodology: Process and product optimization using designed experiments. John Wiley \& Sons, Inc, Hoboken, New Jersey. 2009.

[39] Baş D, Boyacı İH. Modeling and optimization I: Usability of response surface methodology. Journal of Food Engineering. 2007;78:836-845. https://doi.org/10.1016/j.jfoodeng.2005.11.024.

[40] Dent M, Dragović-Uzelac V, Penić M, Brnčić M, Bosiljkov T, Levaj B. The effect of extraction solvents, temperature and time on the composition and mass fraction of polyphenols in dalmatian wild sage (Salvia officinalis L.) extracts. Food technology and biotechnology. 2013;51(1):84-91.

(C) 2021 by the author(s). This work is licensed under a Creative Commons Attribution 4.0 International License (http://creativecommons.org/licenses/by/4.0/). Authors retain copyright of their work, with first publication rights granted to Tech Reviews Ltd. 